\title{
Symposium
}

\section{Will Expansion Work? On Mark Blyth, Austerity: The history of a dangerous idea}

\author{
Wolfgang Streeck \\ Max Planck Institute for the Study of Societies, Cologne. \\ E-mail:ws@mpifg.de
}

\begin{abstract}
Blyth shows convincingly that 'Austerity does not work'. But he seems to imply that financial repression, higher taxes and monetary expansion would. Are they really compatible, however? Financial repression requires growth, real or nominal. Real growth is widely believed to require lower, not higher taxes. Nominal growth, that is inflation, is difficult to contain as well as to bring about, given trade union weakness and widespread dependence on fixed transfer incomes. Monetary expansion, finally, may simply add to general indebtedness, as it has since the late 1970s when real growth embarked on a long-term decline.
\end{abstract}

Comparative European Politics (2013) 11, 722-728. doi:10.1057/cep.2013.23;

published online 9 September 2013

Keywords: EMU; economic growth; Germany; public debt; private debt; expansion; monetary policy

This is a terrific book, exceedingly well-written, a pleasure to read, combining as few others do sound scholarship with powerful political argument. We need more work like this, and urgently given the mess we are in. I particularly like what Blyth has to say on European Monetary Union (EMU), which he correctly describes as the culmination of the various, inevitably unsustainable European exchange rate regimes of the 1970s and 1980s (Chapter 3). 'Einstein', writes Blyth in memorable language, 'is credited with the observation that doing the same thing over and over while expecting different results is the definition of madness. The European monetary project was a bit mad from the get-go. It has only recently revealed itself to be an exercise in insanity' (p. 77f.). This cannot possibly be said better. Applause is also due for the two Chapters (4 and 5) where Blyth traces the intellectual history of austerity; rarely have I seen this sort of story presented so well. Particularly interesting in this context is what Blyth has to say (on p. 165f.) on the Italian dimension of austerity theory and practice and of contemporary neoliberalism in general, especially on the Banca d'Italia, Bocconi University and their ramifications into the international economics profession, the IMF and the European Commission, as recently personified by the 
two Super Marios, Monti and Draghi. ${ }^{1}$ Another gem is Blyth's incisive analysis of what he calls the REBLL countries: Rumania, Estonia, Bulgaria, Latvia and Lithuania, and their economic fate - those places, that is, where 'expansionary austerity' is said by its inventors and practitioners to have worked (p. 216f.).

Why write a comment on a book that must command as much respect and indeed admiration as Blyth's? Fortunately one can always ask questions, extend one or the other line of argument to see where it may lead and probe for underlying assumptions that might usefully be uncovered. Having convincingly demonstrated that 'austerity doesn't work', Blyth in my view remains conspicuously silent on what would work and for whom. This is, of course, entirely legitimate in principle; he or she who undertakes to explain a problem cannot be obliged to deliver a solution as well. However, although Blyth refrains from explicitly telling us what might replace austerity, it seems to me that implicitly he suggests that the alternative is just around the corner, too obvious to be in need of discussion, in the form of monetary and fiscal expansion. It is here that I have my doubts. ${ }^{2}$

Before I get to them, let me reassure the reader that I have not overlooked the last chapter of the book where Blyth does turn policy advocate, if only with respect to public debt, for the reduction of which he recommends a combination of fiscal repression and higher taxes. In recent months that combination seems to have become popular even among governments and their economists, and Blyth is to be commended for having seen this coming. Whether there are good reasons to be as enthusiastic about it as he is, however, a different matter. Fiscal repression is predicated on high growth, real or nominal or a combination of the two, plus low interest rates secured by, presumably, monetary expansion. As to real growth, the problem, nowhere mentioned by Blyth, is that is has been and continues to be on a long-term decline (Figure 1).

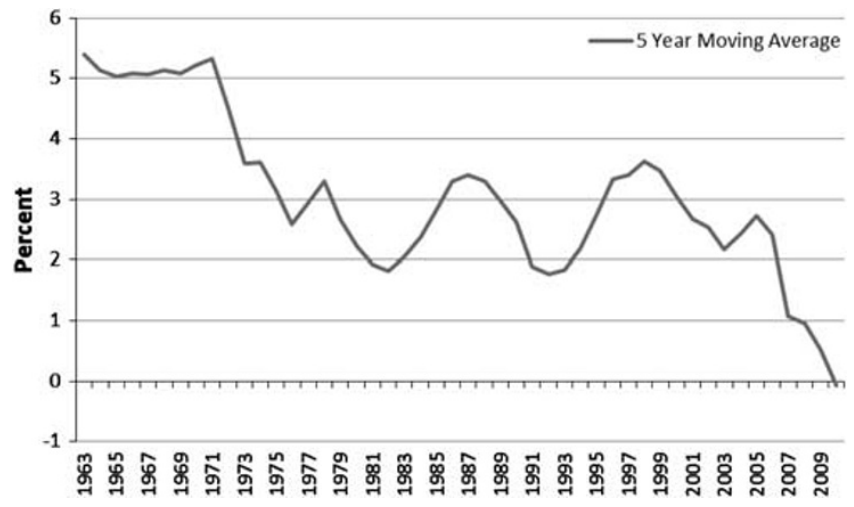

Figure 1: Annual average growth rates of selected OECD countries, 1963-2010.

Note: Countries included in unweighted average: Australia, Austria, Belgium, Canada, Denmark (from 1967), Finland, France, Germany, Greece (from 1971), Ireland, Italy, Japan, the Netherlands, Norway, Portugal, Spain, Sweden, Switzerland (from 1966), the United Kingdom and the United States. Source: OECD economic outlook: Statistics and projections (database). 
Up to now nobody can convincingly say how that trend may be reversed; while opinions differ, however, few if any have suggested that the thing to do would be raising taxes. To the contrary, the mantra has been and still is that growth is stimulated, not by raising but by cutting taxes, promoting investment at the high end of the income distribution or consumption at the lower end. (There is also the minor problem of tax flight, although governments are about to take care of this, or so they say. ${ }^{3}$ ) Hence, the growth trick must almost entirely be done by monetary expansion, and indeed against the odds of the growth-impeding effects of a tax increase.

Fortunately, if the real growth trick refused to work, monetary expansion could also do with the nominal growth trick. Inflation, however, seems hard to engineer in the absence of strong trade unions, that is, by easy money alone. This at least could be the lesson of recent years, when central banks were expanding as though there was no tomorrow but inflation remained miraculously absent. Maybe this would at some point change. However, what would be supposed to cure public indebtedness could have serious side-effects. If easy money eventually did cause inflation, this would disproportionately punish people on fixed incomes. Of these, because of a changed demography, there are many more today than in the 1970s. Moreover, in any case, as we have learned the hard way, easy money could at any moment produce bubbles, like in the run-up to 2008, and throw national economies and the global economy into another boom-and-bust cycle.

Would the Master approve? As I said, there was no lack of easy money for several years now, before the crisis - to which it has in fact contributed - as well as after, again in the United States and later in Japan and, to an extent, in Euroland as well. Why didn't this cause growth, as distinguished from pseudo growth like in the United States and the Mediterranean? I guess Blyth's answer would be, because the fresh money was kept locked up by the banking system and not properly made available to the 'real economy', which is why it better be channeled to governments to fund an expansionary fiscal policy. However, again, would this help? Here is where historical experience should come into play, something that Keynes would clearly have appreciated. For four decades now, public debt has been increasing whereas economic growth declined, again before and after 2008 (Figure 2). At a minimum this would suggest that public debt as such is no magic wand when it comes to stimulating a stagnant capitalist economy. Keynes, I think, would have noticed with astonishment that throughout the post-postwar years, government indebtedness rose almost continuously in most mature capitalist economies, never to be brought down even in the best of times. Moreover, undoubtedly he would also have noticed that this trend began, not just with the end of postwar growth, but also with the arrival of 100 per cent fiat money after the scrapping of the Bretton Woods monetary regime under Richard 'Tricky Dick' Nixon.

The puzzle that we have to solve, in other words, is visible in its full size only if we look at longer trends. Taking the United States as an example, it is not just government debt that has been on the rise for almost half a century, but also the 


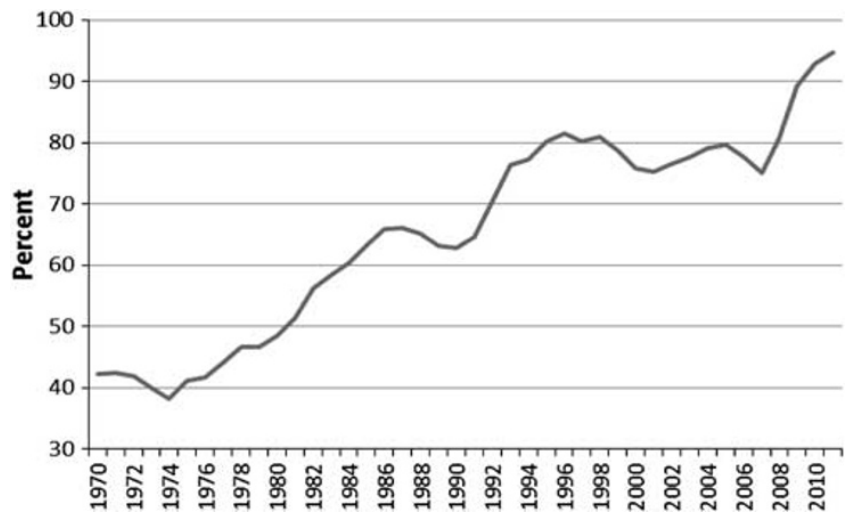

Figure 2: Government debt as a percantage of GDP, selected OECD countries, 1970-2011. Note: Countries included in unweighted average: Austria, Belgium, Canada, France, Germany, Italy, Japan, the Netherlands, Norway, Sweden, the United Kingdom and the United States. Source: OECD economic outlook: Statistics and projections (database).

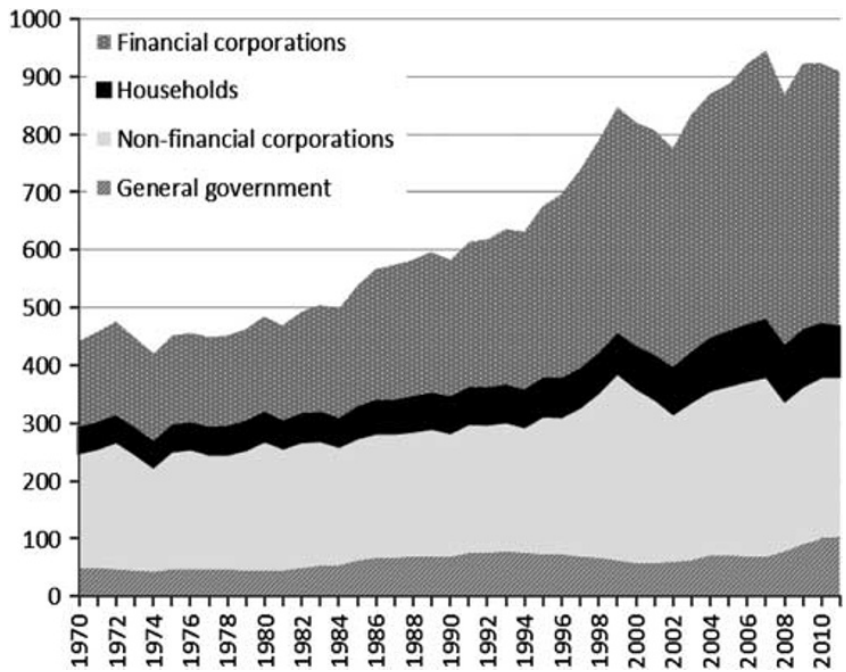

Figure 3: Liabilities as a percentage of GDP by sector, the United States, 1970-2011.

Source: OECD national accounts statistics (database): Financial balance sheets - non-consolidated stocks.

debt of private households and non-financial as well as financial firms. If we add the four kinds of debt we get an astonishingly linear trend since the mid-1970s toward ever higher aggregate indebtedness (Figure 3). And the slope is quite steep. 
Whereas by the mid-1970s overall debt in the US economy amounted to four times the gross domestic product, today it is more than twice as high. Government debt, incidentally, accounts only for the smallest share. Although each kind of debt has grown, the debt of the financial sector has grown most by far, because of continuous financial deregulation as well as an expansionary monetary policy supplying the financial sector with abundant 'liquidity', in an ultimately futile effort at reversing the downward trend in economic growth. ${ }^{4}$

As I said, it is not that monetary expansion had not been tried, in Euroland lately by the Central Bank, in response to popular resistance in Mediterranean countries against fiscal austerity and as Ersatz for the latter. Now, however, there seems to be consensus that this cannot go on indefinitely. After the Bank of Japan had announced its intention in April 2013 to double the country's monetary base within 2 years, the Nikkei 225 rapidly went up from 12000 to almost 15000 points. Only 4 weeks later, however, it lost almost all its gains within half the time, reflecting fears that new bubbles blowing up would render the government's new expansionary growth strategy unsustainable. (The German DAX moved almost in parallel.) Not much later the US Federal Reserve announced that there would soon be an end to 'quantitative easing', which promptly made stock prices worldwide fall even more. In mid-June, then, the Bank for International Settlements in Basel, the mother of all central banks, declared monetary expansion to have reached its limits, handing responsibility for growth and stability back to governments. Central banks, it declared, had in response to the crisis and the slow recovery expanded their balance sheets, "which are now collectively at roughly three times their pre-crisis level - and rising' (Bank for International Settlements (BIS), 2013, p. 5). What follows is worth quoting at some length:

Originally forged as a description of central bank actions to prevent financial collapse, the phrase 'whatever it takes' has become a rallying cry for central banks to continue their extraordinary actions. But we are past the height of the crisis, and the goal of policy has changed - to return still-sluggish economies to strong and sustainable growth. Can central banks now really do "whatever it takes' to achieve that goal? As each day goes by, it seems less and less likely. Central banks ... cannot enact the structural economic and financial reforms needed to return economies to the real growth paths authorities and their publics both want and expect. What central bank accommodation has done during the recovery is to borrow time ... But the time has not been well used, as continued low interest rates and unconventional policies have made it easy for the private sector to postpone deleveraging, easy for the government to finance deficits, and easy for the authorities to delay needed reforms in the real economy and in the financial system. After all, cheap money makes it easier to borrow than to save, easier to spend than to tax, easier to remain the same than to change (ibid.).

What are governments, absent unlimited money, supposed to do according to the wisdom of the stewards of the global money supply, which is that the supply of 
money cannot be unlimited and that aggregate debt cannot rise forever, lest people lose confidence that the accumulated promises money represents can in fact be kept some day in the future? The rat we smell here is the same animal that has haunted us for several decades now: neoliberal institutional reform, as summarized in the second subtitle of the BIS (2013) Annual Report: 'Enhancing flexibility: A key to growth' (p. 6) - the bitter medicine for the many, combined with more attractive incentives for the few. The Master, it appears, had returned only for a few months. Cheap money will not be provided forever by central bankers, and not without 'conditionality'. Draghi and friends may not be able to produce sound money, but they clearly know the value of sound profits in a capitalist economy. Even Blyth seems to have forgotten Keynes' most fundamental insight: that unlimited money - free capital, as it were - would both cause and indeed require a 'euthanasia of the rentier'. As long as $\mathbf{M}$ is to become M', surplus must be extracted, and for this market discipline is indispensable. Perhaps Blyth should have taken more seriously the fact that what he calls the economy is in fact a capitalist economy?

Mark Blyth has brilliantly shown that Austerity does not work. However, he has failed to consider the possibility that expansion may not work either - that, in other words, we may be facing a dilemma, one deriving from more powerful causes than general German stupidity, the unlikely survival of Ordoliberalismus in Freiburg, or the intellectual hegemony of Bocconi economics in international organizations. The question we may have to ask is whether there is a 'third way' for OECD capitalism between lack of aggregate demand on the one hand and the booms and busts of a capitalist zombie economy under artificial respiration. The answer might well be that there is none. Perhaps we should start thinking about what that could mean.

\section{Notes}

1 Presented by Blyth under the wonderful subtitle, There is a Free Pranzo if You Skip Your Cena: The Italian Origins of Expansionary Austerity.

2 I also have doubts on Blyth's essentially ideational interpretation of the position of the German government in the present conflicts over Europe and the Euro. Blyth forgets that until the middle of the 2000s, Germany was 'the sick man of Europe', allegedly because it had failed to restructure toward a 'service economy'. In those years Ireland's per capita income was statistically higher than Germany's, and Spain with its apparently booming economy was by some featured as a model for Germany to emulate. 2008 showed how fragile the sudden wealth at the European periphery really was, and how dangerous for everybody else. No German government in its right mind can opt for a return to the politics of easy money - based on interest rate convergence and an EMU nominal interest rate above the German inflation rate - that had caused this calamity, given the peculiar nature of the German economy as a center of advanced, export-oriented manufacturing.

3 Skeptic that I am, I tend to believe that the present noise about rooting out the global tax havens is fundamentally no more than a political smokescreen for soon-to-come increases in value-added tax, payroll taxes and social security contributions.

4 To be sure, even if we took the financial sector out, to look only at government, households and the 'real' economy, there would be a steep increase in indebtedness from roughly 200 to almost 500 per cent of GDP. 


\section{About the Author}

Wolfgang Streeck is Professor of Sociology and Director at the Max Planck Institute for the study of Societies in Cologne.

\section{References}

Bank for International Settlements (BIS). (2013) 83rd Annual Report, 1 April 2012-31 March 2013. Basel: Bank for International Settlements (BIS). 